\title{
THE SOURCES OF AUXIN HORMONE TO \\ GROWTH OF SHOOT PINEAPPLE STEM CUTTING \\ (Ananascomosus.L. Merr.)
}

\author{
Palupi Puspitorini \\ Balitar Islamic University of Islam, Blitar \\ Email: puspitorini.palupi@gmail.com
}

\begin{abstract}
The aim of this study was to select the best sources of auxin of which it can stimulate the growth of shoots Pineapple plant cuttings. This research is compiled in a completely randomized design (CRD) with 4 treatments and 6 replications. The Data were statistically Analyzed by the DMRT. Level of treatment given proves that no treatment $0 \%$, cow urine concentration of $25 \%$, young coconut water concentration of $25 \%$ and Rootone F $100 \mathrm{mg} /$ cuttings. The results showed that cow urine concentrations of $25 \%$ and Rootone F $100 \mathrm{mg}$ give the best results in stimulating the growth of shoots pineapple stem cuttings. Experimental results concluded that the effect of this natural hormone were better than the shoots without given hormone.
\end{abstract}

Keywords: auxin, pineapple plant, cutting, treatments.

\section{Received: 15 Jaunary 2016; Accepted: 15 March, 2016}

\section{INTRODUCTION}

In general, pineapple plants grow in the range of rainfall is about $1000-1500 \mathrm{~mm}$ year $^{-1}$. Pineapple is suitable to be planted at an altitude of $800-1200 \mathrm{~m}$ above the sea level. Pineapple plant optimum growth between 100-700 m above sea level. In general, almost any type of soil used for agriculture which suitable for pineapple plants (Sunaryo, 2004).

Despite this growth is more suited to the type of soil containing sand, fertile, loose and high in organic matter and has a low lime content. A suitable degree of acidity is $\mathrm{pH} 4,5-6.5$ points. The Soil that contains lime ( $\mathrm{pH}$ greater than 6.5) cause plants to become stunted and chlorotic While that acidic soil ( $\mathrm{pH} 4.5$ or lower) result in a decrease in the elements Phosphorus, Potassium, Sulfur, Calcium, Magnesium, and Molibdinum. (Judge L, 1986).

Pineapple plants can grow at an altitude of $600-2000 \mathrm{~m}$ above the sea level. Nonetheless, growth and optimal production is produced at an altitude of more than $1,500 \mathrm{~m}$ above the sea level. Rainfall needed is 1,500-2,000 $\mathrm{mm}$ per year with low temperatures. In general, pineapple plants can grow on various types of soil. Pineapple grow in sandy soil containing humus, and having a $\mathrm{pH}$ of 6 to 7.5. Pineapple can also grow on acidic soil, but must be neutralized by adding manure or lime.

The growth of shoots on the cuttings is influenced by growth of auxin hormone. The function of this hormone is to spur the growth of shoots on the cuttings of pineapple plants. This hormone can be in the form of synthetic or organic (natural) (Pratt, 2010). So in this experiment it will conduct various natural hormone auxin 
treatment this is applied to the stem plant cuttings of pineapple (Ananascomosus L. Merr.)

In big companies, integrated farming pineapple which has an area of tens of thousands of hectares that the pineapple plant breeding is essential once it is known. During this time the seeds come from the crown (crown), sucker (buds), slip (side shoots), which amount is not balanced with the needs of seed. Then propagation by stem cuttings will be tried so that there is an alternative way of obtaining seeds fast and has good quality.

The purpose of this study was to select the best source of auxin to stimulate and accelerate the growth of plant shoots stem cuttings of pineapple (Ananascomosus L. Merr.)

\section{MATERIALS AND METHODS}

The experiment was conducted in Central Lampung Regency of Lampung province at an altitude of $0 \mathrm{~m}$ above the sea level. Implementation was at the end of January to May 2011.

Materials used are the stem of pineapple plant cayyene varieties. Stem of pineapple plants will be in cuttings 2 years old, a small cut (section), and cow urine, coconut milk, powdered Rooton-F, distilled water, cow manure, seedbox, rice husks and other materials required for the manufacture of cuttings.

These experiments are arranged according to completely randomized design (CRD) with 4 treatments and 6 replications. Entirely made up of 24 experimental plots, each plot contained 4 and 2 pineapple plants sampled. The data obtained will be analyzed by Analyzing of Varian Test (Anova) 5\% that will be continued with the test of Duncan's Multiple Range Test (DMRT).

Bed made collectively with a length of $3 \mathrm{~m}$, a width of $2 \mathrm{~m}$, a height of $1.5 \mathrm{~m}$. Shading is made of bamboo, while the roof and walls of transparent plastic to regulate the lighting during the seeding process, in which the incoming light about 20 or $30 \%$

Observations of the time show that bud cuttings by counting the number of days required for each plant sample after planting until shoots appear. The criteria is when the shoots appear on the cuttings have come out shoots with a minimum length of 0.5 $\mathrm{cm}$.

Observations is taken if the length of the longest shoots cuttings has issued more than $0.5 \mathrm{~cm}$ shoots. Measurement starts from the base of the buds to the growing point. Observations longest hoots were done by measuring the longest shoots at the time of observation. Subsequent observations are made every week until 16 weeks of old seedlings.

The number of roots per cuttings at the end of the study, ie 16 weeks after planting by splitting a polybag then media cuttings were inserted into a container filled with water, then shaken so that the roots are not severed. After that, all the roots out on the base of the seedlings have been calculated that a minimum length of $2 \mathrm{~cm}$.

Measurements were carried out after the completion of the longest root number of stake observation, at week 16 after planting by measuring the longest roots from the base of the root to the tip of the root.

Fresh weight of shoots was measured at the end of the study, ie at week 16 after planting. The way to cut the whole shoots from the base to the growing point was done carefully, then weigh the fresh weight. 
Root fresh weight measurements were carried out at the end of the study, i.e. at week 16 after planting. by separating the roots of the seedlings carefully and weighed fresh weight. Measurement of root dry weight was done at week 16 after planting.

\section{RESULTS AND DISCUSSION}

Giving cow urine concentration of $25 \%$, young coconut water concentration of $25 \%$ and Rootone F $100120 \mathrm{mg} /$ cuttings showed significantly different influence on the time of the first shoots appear. Results of D MRT (15\%) are presented in Table 1. 
Table 1.StemcuttingsPineappleshoot in someplantgrowthregulator

\begin{tabular}{|c|c|c|}
\hline Growth Regulator & $\begin{array}{l}\text { The first shoot } \\
\text { grow(day) }\end{array}$ & $\begin{array}{l}\text { Length of the longest } \\
\text { shoots }(\mathrm{cm})\end{array}$ \\
\hline No Hormone & $45,17 \mathrm{a}$ & $2,67 \mathrm{c}$ \\
\hline Cow Urine $(25 \%)$ & $35,33 \mathrm{~b}$ & $16.00 \mathrm{a}$ \\
\hline Young Coconut Water ( $25 \%)$ & $30,83 \mathrm{~b}$ & $8,83 \mathrm{~b}$ \\
\hline Rootone F $120 \mathrm{mg} /$ cutting & $28,67 \mathrm{~b}$ & $6,17 \mathrm{bc}$ \\
\hline
\end{tabular}

Effect of cow urine concentration of $25 \%, 25 \%$ coconut water concentration and Rotoone F $120 \mathrm{mg} /$ cuttings showed the same effect. The three types of plant growth regulator shows the time arises shoots faster than without hormones. This gives an indication that the various treatment containing auxin will accelerate the emergence of shoots. Provision of exogenous auxin (from the outside) will increase the activity of endogenous auxin already exist on cuttings, so as to encourage cell division and cause the buds appear earlier. No hormones appear that the shoot is longer than others, such as age 45.17 HST. This is because the natural plant growth regulator that of the cuttings (endogenous) slown stimulate cell division and elongation, so the age of the buds appear to be longer (Rismunandar, 1992)). Reviewed by plant growth regulator, by plant growth regulator Rotoone F $120 \mathrm{mg}$ / cuttings fastest influence in stimulating bud cuttings. It is assumed that the number of auxin contained are in the exact amount which then interacts with the plant growth regulator others contained in material cuttings such as cytokinin and auxin working together for the occurrence of cell division and increased-the activity of certain enzymes in stimulating protein synthesis ( Rochiman and Harjadi, 1973).

Table 2.Rooting of stemcuttings of Pineapple at $16 \mathrm{WAP} *$ forsomeplantgrowthregulator

\begin{tabular}{lll}
\hline Growth Regulator & $\begin{array}{l}\text { Number } \\
\text { of root }\end{array}$ & $\begin{array}{l}\text { Length of } \\
\text { the longest } \\
\text { shoots(cm) }\end{array}$ \\
\hline $\begin{array}{l}\text { No Hormone } \\
\text { Cow Urine }(\mathbf{2 5 \%})\end{array}$ & $3.00 \mathrm{~b}$ & $8.67 \mathrm{~b}$ \\
$\begin{array}{l}\text { Young Coconut Water } \\
\text { (25\%) }\end{array}$ & $5.83 . \mathrm{a}$ & $32.17 \mathrm{a}$ \\
$\begin{array}{l}\text { Rootone F 120 } \\
\text { mg/cutting }\end{array}$ & $3.50 \mathrm{~b}$ & $24.50 \mathrm{a}$ \\
\hline
\end{tabular}

*) WAP week After planting

Giving cow urine concentration of $25 \%$, young coconut water concentration of $25 \%$ and Rotoone F $120 \mathrm{mg} /$ cuttings showed significantly different influence on the longest shoot length than that of any other plant growth regulator. This is because Rotoone F contains the active ingredient in the form of naftalenasetamida $0.067 \%, 2$ methyl 1 naftalenasetamida $0.013 \%, 2$ methyl 1 naphthalene acetic $0.033 \%$, indole 3 butyric (IBA) $0.057 \%$, and oysters 4\% (Sutarto, IM, et al, 1991 ). The combination of active ingredients of this type is more effective in stimulating the growth of long shoots of pineapple. With no hormones producing the most short shoots, it is suspected because of the activity of endogen hormones very slowly making it less effective to accelerate the process of cell division and cell differentiation. Growth in the bud long was associated with cell division and cell length, otherwise the formation of buds is more affected by the differentiation of meristematic cells.

Shoot length growth is influenced by hormones of auxin and cytokinin. Cytokines will stimulate cell division through increased rate of protein synthesis, whereas auxin will spur the 
elongation of the cells that cause stem elongation. Mechanism of action of auxin in influencing an extender-plant cells can be explained as follows, auxin spur protein in the plasma membrane of plant cells to pump $\mathrm{H}+$ ions into the cell wall. These $\mathrm{H}+$ ions activate certain enzymes, so decided some hydrogen chain cross linking the cellulose molecules making up the cell wall. Plant cells, then more elongated due to the incoming water by osmosis. After elongation, the cells continued to grow with the return material to synthesize the cell wall and cytoplasm.

Giving cow urine concentration of $25 \%$, young coconut water concentration of $25 \%$ and Rotoone F $120 \mathrm{mg}$ / cuttings showed significantly different effect on the number of roots per seedling.

Provision of plant growth regulator cow urine concentrations of $25 \%$ and Rotoone $\mathrm{F} 120$ $\mathrm{mg} /$ cuttings shows the formation of roots more than the provision of plant growth regulator coconut water concentration of $25 \%$ and the treatment without hormones. This is because Rotoone F $120 \mathrm{mg}$ / cuttings containing NAA and IBA were more active in encouraging the formation of roots. In accordance to the opinion of Rochiman and Harjadi (1993) that the IBA is more stable, so the longer persistence and mobility in low plant that provides more possibilities of success of root formation. To form its roots, auxin should be available continuously, so as to further growth and development in spurring sufficient root length and root number. In addition, the benefits of cow urine is having a complete nutrient content such as $\mathrm{N}, \mathrm{P}, \mathrm{K}, \mathrm{Ca}, \mathrm{Fe}, \mathrm{Mn}, \mathrm{Zn}$, and $\mathrm{Zu}$. The cow urine also contained the hormone substances stimulate growing type of auxin. Giving cow urine can influence the growth of plants that can be seen from the number of roots formed more.

Giving cow urine concentration of $25 \%$, young coconut water concentration of $25 \%$ and Rotoone F $120 \mathrm{mg} /$ cuttings showed significantly different influence on the length of the longest root.

The length of the longest root of the provision contained in the plant growth regulator treatment of cow urine concentration of $25 \%, 25 \%$ coconut water concentration and Rootone F $100 \mathrm{mg} /$ cuttings. This is because the concentration of exogenous hormones contained in each plant growth regulator that is translocated able to increase the length of the roots so as to enhance the physiological processes in the cell, which affects the development and cell elongation. While no hormones have long roots of the lowest compared with the others, namely $9.67 \mathrm{~cm}$. Root length is closely related to the number of roots formed, if the number of roots that formed are many, then the ability of the roots to absorb nutrients are also higher. Assimilates are formed also are getting higher and assimilates will be translocated to all parts of the body as well as to growth.

Table 3.Weight of Wet and DryBranchStem and RootCropsPineapple 16 WAP* At

\begin{tabular}{lcccc}
\multicolumn{2}{c}{ Someplantgrowthregulator } & \multicolumn{3}{c}{} \\
\hline \multicolumn{1}{c}{ Growth Regulator } & $\begin{array}{c}\text { Shoot Fresh } \\
\text { weight (g) }\end{array}$ & $\begin{array}{c}\text { Shoot Dry } \\
\text { Weight (g) }\end{array}$ & $\begin{array}{c}\text { Root Fresh } \\
\text { Weight (g) }\end{array}$ & $\begin{array}{c}\text { Root Dry } \\
\text { Weight (g) }\end{array}$ \\
\hline No Hormone & $1,65 \mathrm{c}$ & $0,09 \mathrm{~b}$ & $0,25 \mathrm{c}$ & $0,27 \mathrm{~b}$ \\
Cow Urine (25\%) & $18,78 \mathrm{ab}$ & $1,74 \mathrm{a}$ & $2,27 \mathrm{ab}$ & $1,89 \mathrm{a}$ \\
Young Coconut Water (25\%) & $17,13 \mathrm{~b}$ & $1,35 \mathrm{a}$ & $1,24 \mathrm{bc}$ & $1,44 \mathrm{a}$ \\
Rootone F 120 mg/cutting & $22,65 \mathrm{a}$ & $1,94 \mathrm{a}$ & $2,79 \mathrm{a}$ & $2,15 \mathrm{a}$ \\
\hline
\end{tabular}

*) WAP Week After Planting

Table 3 shows the effect of cow urine concentration of $25 \%$, young coconut water concentration of $25 \%$ and Rotoone F $120 \mathrm{mg}$ / cuttings showing significantly different effect on fresh weight of shoots. 
Provision of plant growth regulator Rotoone F $120 \mathrm{mg} /$ cuttings and cow urine concentration of $25 \%$ has the highest weight in comparison with the fresh shoots of young coconut water concentration of $25 \%$ and without hormones. This correlates closely with shoot length parameters. Correlation of fresh weight of shoots with the previous parameter due to the fresh weight of shoots an accumulation of wet weight of branches and leaves. The rapid buds appear if the process plant growth would be faster thus increase plant height and number of leaves produced higher also. Plant height and number of leaves will lead to weight increased (Irwanto, 2001).

Giving cow urine concentration of $25 \%$, young coconut water concentration of $25 \%$ and Rotoone F $120 \mathrm{mg} /$ cuttings showed significantly different effect on the dry weight of shoots.

Dry weight of shoots obtained the highest plant growth regulator invitation granting cow urine concentration of $25 \%, 25 \%$ coconut water concentration and Rotoone F $100 \mathrm{mg} /$ cutting, this data is positively correlated with fresh weight of shoots. Observations obtained previously for fresh weight gives a significantly different effect, indirectly clicking also causes the same effect on the accumulation of dry weight.

The shoot fresh weight and dry weight of shoots relate to the number of leaves, shoot length and fresh weight of shoots. Shoots dry weight is the result of leaf photosynthesis and nutrient absorption by the roots. Plant dry weight is a measure of determining the quality of plant growth and yield of a plant that is the result of the process of photosynthesis, decreased assimilate and translocation into the organs of plants.

Giving cow urine concentration of $25 \%$, young coconut water concentration of $25 \%$ and Rotoone F $120 \mathrm{mg}$ / cuttings showed significantly different effect on fresh weight of roots.

Provision of plant growth regulator cow urine concentrations of $25 \%$ and Rotoone $\mathrm{F} 120$ mg / cuttings showed the highest root fresh weight than that of plant growth regulator coconut water concentration of $25 \%$ and without hormones. Root volume is closely related to the number of roots and root length produced by the plant. Giving cow urine concentrations of $25 \%$ and Rotoone F $120 \mathrm{mg} /$ cuttings have more root number and root length of the longest, so the fresh weight of the roots have a higher weight, it is also associated with growth. Where the provision of cow urine concentrations of 25\% and Rotoone F $120 \mathrm{mg} /$ cuttings have a shoot length longer than without hormones. Shoot growth was also influenced by the roots plants. The roots functions as part of the plant to absorb nutrients. Good root growth also digest the good flect shoot growth.

Giving cow urine concentration of $25 \%$, young coconut water concentration of $25 \%$ and Rootone F $100 \mathrm{mg}$ / show significantly different effect on the root dry weight.

Provision of plant growth regulator cow urine concentration of $25 \%, 25 \%$ coconut water concentration and Rotoone F $120 \mathrm{mg} /$ cuttings had the highest root dry weight compared with no hormones. This is because the right-Dungan exogenous hormones were translocated able to stimulate the cells at the root end to division and lengthening root (Netty, WD, 2001). The number of lots and long roots absorb water and nutrients to the maximum causing increased fresh weight and root dry weight were produced.

\section{CONCLUSION}

Based on the results of experiments that have been done can be concluded that the granting of cow urine concentration of $25 \%$, young coconut water concentration of $25 \%$ and Rootone F $120 \mathrm{mg} /$ cutting, in this experiment provides a real influence on all of the 
variables observation. While Rotoone F $120 \mathrm{mg} /$ cuttings and cow urine concentration of $25 \%$ is the best source of auxin to stimulate root growth of plants pineapple stem cuttings

\section{REFERENCES}

Hakim, M. Yusuf N. A. Lubis, S. G. Nugroho, M. R. Saul, M. A. Diha,G.B. Hong dan H. H. Barley. 1986. Dasar-DasarIlmutanah. Universitas Lampung. 326 hal.

Irwanto.2001. PengaruhHormon IBA (Butyric Acid) Terhadap Persen Jadi stek Pucuk Meranti Putih (Shoreamontigena). Universitas Pattimura. Ambon.26 hal.

Netty W, D. 2001. Peranan Beberapa Zat Pengatur Tumbuh (ZPT) Tanaman Pada Kultur In Vitro. Jurnal sains dan teknologi Indonesia Vol. 3.No. 5. 55-63

Pratama, Y. 2010. Pengaruh Pemberian Beberapa Zat Pengatur Tumbuh Terhadap Keberhasilan Setek Kakao (Theobrema cacao L.). Skripsi. Universitas Andalas. 45 hal.

Rismunandar. 1992. Hormon Tanaman dan Ternak. Penebar Swadaya. Jakarta. 58 hal.

RochimandanHarjadi. 1973. Pembiakan Vegetatif. Departemen Agronomi. Fakultas Pertanian IPB. Bogor. 70 hal.

Sutarto.I M, Juwal As danWijaya.1991. Pengaruh IBA dan Pengetahuan Terhadap Keberhasilan Rambutan Binjai. Penelitian Hortilkultura. Stigma vol. 4 no. 2.

Sunarjo, H. 2004. Berkebun 21 Jenis Tanaman Buah. Penebar Swadaya. Jakarta. 60 hal. 
JARES, Vol. 1 No. 1 March, 2016; p-ISSN: 2502-826X; e-ISSN: 2503-1163

Copyrights@ Balitar Islamic University, Blitar, Indonesia; Http://jares.unisbablitar.ejournal.web.id

Citation: Puspitorini, Palupi. 2016. The Sources of Auxin Hormone to Growth of Shoot Pineapple Stem Cutting (Annascomosus.L.Merr.) JARES, (2016), 1(1): 45-52. 